\title{
The effect of family ownership on accrual- based and real activities based earnings management: Evidence from the French context
}

\author{
Zeineb Feki Cherif ${ }^{\text {a }}$, Salma Damak Ayadi ${ }^{\text {b, } 1}$ and \\ Saoussen Boujelben Ben Hamad ${ }^{c}$ \\ ${ }^{a}$ LIGUE, University of Manouba \\ ${ }^{b}$ IHEC Carthage, University of Carthage, LIGUE, University of Manouba \\ ${ }^{c}$ ESC, URAMEF, University of Sfax
}

\begin{abstract}
Research Question: What is the effect of family ownership on accrual-based earnings management (ABEM) and on real earnings management (REM)? Motivation: Despite the importance and the predominance of family companies among the worldwide listed firms, there is a few study having examined earnings management in family businesses when compared to non-families ones. Their particular characteristics distinguishing them from typical public companies, family firms could provide an interesting setting for the purpose of investigating their earnings quality. Idea: Using agency theory and socio-emotional wealth (SEW) theory, we suggested and explained the impact of family ownership on earnings management. Data: We analyze a sample of French firms listed in CAC All-Tradable index in the period ranging from 2014 to 2016. Tools: We adopts the Generalized Least Squared (GLS) technique correcting heteroskedasticity and serial correlation problems related to panel data. Findings: We document that family ownership has no significant effects on ABEM, but it has a positive and significant influence on REM. In fact, this study conducted on French family firms shows that they are more involved in upward earnings management than nonfamily firms. Our results supports the hypothesis that family firms suffer from type II agency problems, and it can be explained by the desire to ensure the control and

\footnotetext{
${ }^{1}$ Corresponding author: Salma Damak Ayadi, Full Professor, IHEC Carthage, University of Carthage, Tunisia, Member of the LIGUE LR99ES24, ISCAE, University of Manouba, Email: salmadamak@yahoo.fr
} 
influence among the firm. Contributions: This study is expected to increase the understanding of the family firms' behavior in terms of their earnings management practices building on the both agency and SEW theory.

Keywords: family ownership, accrual-earnings management, real earnings management, agency problem, socio-emotional wealth.

\section{JEL code: $M 41$}

\section{Introduction}

Financial scandals (Enron and Worldcom in the USA, Vivendi in France etc.) have created problems related to the quality of the financial statements, especially that of the earnings indicator. Due to these financial scandals, the attention of researchers and legislators has been given to earnings management, and to its impact on the quality of accounting and financial information. The earnings management practice leads to the fraudulent presentation of financial statements, and consequently to misleading investors (DeFond \& Park, 1997; Labelle, 1990).

A great deal of research is dedicated to study the earnings management in public firms. However, there is a little study having examined earnings management in family businesses when compared to non-family ones (Salvato \& Moores, 2010). Because of their importance and predominance among the worldwide listed firms (80\% of companies ${ }^{1}$ ) and their particular characteristics distinguishing them from typical public companies, family firms could provide an interesting setting for the purpose of investigating their earnings quality.

Even previous studies have produced mixed results. On the one hand, some researches based on US firms have concluded that family firms have a better financial quality disclosure (Ali et al., 2007; Jiraporn \& DaDalt, 2009; Martin et al., 2016; Tong, 2007; Wang, 2006). Similar findings have been found out in German and Italian family firms (Achleitner et al., 2014; Cascino et al., 2010; Prencipe et al., 2008). These studies have noted that family companies have less serious Type I agency problem, justifying the lower level of earnings management in family firms. On the other hand, for other countries, there are conclusions indicating that family firms are more engaged in earnings management than nonfamily ones (Chi et al., 2015; Ding et al., 2011; Razzaque et al., 2016). These researches have given proof that family firms suffer from Type II agency conflicts. As a result of ownership concentration, the agency problem shifts from a managershareholder(s) conflict to that of majority-minority shareholders, given that there is a great potential of family owners' expropriating actions. Hence, family firms 
engage more in earnings management. Therefore, the two types of agency conflicts can determine the level of earnings management in family firms.

Despite these different outcomes, most prior studies have looked into financial information quality provided by family firms, focusing on accrual-earnings management (hereafter ABEM) (Ali et al., 2007; Martin et al., 2016; Prencipe et al., 2014; Stockmans et al., 2010). To the best of our knowledge, there is little research on real earnings management (hereafter REM) in family business (Achleitner et al., 2014; Chen et al., 2015; Razzaque et al., 2016). However, doing research on REM in family firms is substantial. Indeed, owner family members are often the managers of the firms (Anderson \& Reeb, 2003), bringing about an alignment of interest between family owners and managers. This collusion favors the manipulation of real activities in order to appropriate benefits to the detriment of other shareholders, which may be denied by the concern for the potential negative effect of REM (Cohen \& Zarowin, 2010; Graham et al., 2005; Roychowdhury, 2006). What is more, family shareholders are less likely to adopt actions having a negative influence on the firm's future value because of their long-term orientations (Stein, 1989). Therefore, REMs in family firms remains a topic for further research.

Moreover, most previous studies have been based only on agency theory to account for the link between family firms and earnings management. In our study, we propose another explanation, aiming to predict this relationship. This explanation consists in the socio-emotional wealth (SEW) theory which has been developed within the field of family business research (Cennamo et al., 2012; Prencipe et al., 2014). The advanced idea of this theory is that the main objective of family firms is the preservation of their "non-financial-affected related value" (Prencipe et al., 2014: 366).

Our research works towards exploring the effect of family ownership on ABEM and REM. Thus, we adopt both agency theory and SEW as a theoretical framework. As matter of fact, agency theory posits that in family firms, the traditional owner-manager agency conflict (Jensen \& Meckling, 1976) is mitigated owing to their reduced separation of ownership and management. However, this alignment of interest between managers and owners brings about another type of agency conflicts: the problems between minority and majority shareholders (Fama \& Jensen, 1983). Hence, this agency conflict results in incentives for earnings management to expropriate minority shareholders (Ding et al., 2011). SEW theory states that family owners are not only motivated by economic aspects of business, but they are also concerned with non-financial objectives (Berrone et al., 2012). They use SEW conservation as the key basis for assessment, drawing on the SEW preservation model which points out that earnings management is a gamble (Gómez-Mejía et al., 2007). According (Berrone et al., 2012), the SEW concept is multidimensional. It encompasses five dimensions labelled "FIBER": "Family 
control and influence, Identification of family members with the firm, Binding social ties, Emotional attachment, and Renewal of family bonds to the firm through dynastic succession" (Berrone et al., 2012: 259). These SEW dimensions are the leading features that give family firms exceptional qualities, and run their policy decisions (Berrone et al., 2012; Gómez-Mejía et al., 2010). However, a number of researches imply that these SEW dimensions could influence differently, in accordance with the family owners' inclination (Berrone et al., 2012; Cennamo et al., 2012). Hence, Gómez-Mejía et al. (2014: 388) note that "the result of the gambling processes would be different among family owners, depending on their most salient SEW reference point". Given that some authors (Gómez-Mejía et al., 2007; Strike et al., 2015) have reported that the two most important SEW dimensions are "Family control and influence" and "the Renewal of family bonds to the firm through dynastic succession"; we focus attention in this research on these two dimensions for the sake of foreseeing and accounting for the relation between family firms and earnings management. Indeed, the 'Family control and influence' dimension refers to a strong will on the part of family members to perpetuate family control and influence within its business (Berrone et al., 2012), which can be an inducement for engaging in earnings management regardless of financial gains. However, when the trans-generational sustainability is more prominent, family members are more likely to avoid earnings management practices having a negative effect on the future performance and future earnings of the firm (Achleitner et al., 2014; Gunny, 2005; Rodriguez-Ariza et al., 2016).

Accordingly, we establish two alternative hypotheses. Firstly, since family firms are characterized by a less serious type I agency problem, and in order to ensure the trans-generational sustainability, family owners are less likely to engage in incomeincreasing earnings management practices having a negative impact on the future performance and value of the firm. Secondly, we argue that so as to seek private gains at the expense of other minority shareholders (Type II agency problem), and for maintaining control and influence among the business, managers in family firms are more likely to engage in earnings management than those in non-family firms.

These arguments are tested in French companies listed in the CAC All-Tradable over the period between 2014 and 2016. The French equity market represents an ideal setting for investigating the influence of family ownership on earnings management for the following reasons: (a) there is a huge number of listed family firms (between 60 and 70\% according to various studies: PWC, KPMG, INSEE); (b) there is a high degree of ownership concentration across all listed firms (La Porta et al., 1999); (c) it represents a particular institutional environment characterized by a low investor protection. The investor protection is a leading factor affecting firms' ability to engage in earnings management (La Porta et al., 2006; Leuz et al., 2003); and (d) to the best of our knowledge, there are few studies dealing with this issue in the French context (Mard \& Marsat, 2012). Mard and 
Marsat (2012) examined the practice of earnings management in French companies, taking into account the different types of ownership (managerial, family, institutional, financial, and State). They used discretionary accruals so that they could measure earnings management. Thus, it is important to consider the impact of family ownership on earnings management practices (ABEM and REM) in the French context.

Our results show that family ownership has no effect on ABEM, so there is no significant difference between ABEM in family firms and in non-family ones. However, family ownership has a positive and significant impact on REM. Hence, our study provides two main conclusions. To start with, we provide evidence that family companies in France are more engaged in earnings management practices (via REM) than non-family ones. Second, we evince that family firms use real activities to manipulate earnings. These results are consistent with Chen et al. (2015) and Razzaque et al. (2016). We could explain our findings as follows. To begin with, family firms have more serious agency problems between the controlling family and the minority shareholders (type II agency problem). Second, given that we have relied on the two main dimensions of the SEW theory to predict the effect of family ownership on earnings management, it is worth saying that French family firms are more likely to prevail the control and influence aspect of SEW theory than the trans-generational sustainability. Thus, aiming for ascertaining the control and the influence among the firm, family owners engage in earnings management. Hence, longing for maintaining control and influence among firms deepens the agency problems between family owners (majority shareholders) and other shareholders (minority shareholders). Third, family firms give an interesting framework for the REM practices. The position of family members established and implanted allows them to have a direct access to real activities. Fourth, while the manipulation of accruals often takes place at the end of the fiscal year, REM may occur at any time of the year. Finally, ABEM can be easily detected by auditors, regulators, and independent directors (Klein, 2002; Zang, 2011) whereas it is difficult for REM to detect and distinguish other economic transactions of the company.

This paper contributes to the family business and earnings management literature in many ways. First of all, our findings add to the studies on the quality of financial information in family business. In fact, unlike the prior studies having only focused on ABEM (Ali et al., 2007; Prencipe et al., 2014; Stockmans et al., 2010), our research explores the two methods of earnings management: ABEM and REM. Second, most previous studies have been based on the agency theory to explain the relation between family firms and earnings management. The current study also uses the SEW theory offering a clearer framework to investigate this relationship. Thus, the pursuit of financial objective can be secondary to the SEW preservation. Indeed, a set of empirical studies shows how SEW foresees different strategic choices (Berrone et al., 2010; Gómez-Mejía et al., 2011; Gómez-Mejía et al., 
2010). Therefore, it is of great importance to consider this non-economic goal to predict and account for the earnings management in family firms. Third, this research reveals that family owners seeking to preserve control and influence among firms make accounting choices that increase income at the expense of other objectives such as future performance. Finally, our results add to the literature through presenting the experimental proof of earnings management in family corporations in an advanced economy, and these outcomes could be more common in contexts identical to France regarding the impotent institutional patronage.

The remainder of this paper is organized as follows. In the next section, we will depict the theoretical framework we use to develop the hypothesis. In the subsequent section, we present the methodology of study: the data, and the empirical model. Finally, we will discuss our results, and conclude.

\section{Theoretical framework and research hypothesis}

\subsection{Theoretical framework}

We have used two main theoretical frameworks in this study: agency theory and SEW theory. According to the agency theory, the firm is defined as "a contract under which one or more persons (the principal(s)) engage another person (the agent) to perform some service on their behalf, which involves delegating some decision making authority to the agent." (Jensen and Meckling, 1976: 308). One of the features of widely-held firms is the separation between ownership and control, leading to agency conflicts between the manager and the owner (Jensen \& Meckling, 1976). Hence, family firms are characterized by a concentrated ownership, and they are run by multiple family members (Paiva et al., 2016), which reduces the traditional owner-manager conflicts (Type I agency problem). Some studies have shown that the concentration of ownership makes managers be subjected to effective close scrutiny. The better control of management can mitigate the managerial opportunistic behavior, so it can reduce earnings management practices (Achleitner et al., 2014; Pazzaglia et al., 2013; Prencipe \& Bar-Yosef, 2011).

Majority and minority shareholders are two distinct groups of shareholders resulting from the family ownership concentration nonetheless. Accordingly, this can create a new agency problem consisting in a conflict between the controlling family and the minority shareholders (Type II agency problem). A controlling family has an opportunity to maximize its private benefits through expropriating minority shareholders. Hence, the majority shareholders (family) involved in the firm management handle the results so that they could have private interests to the detriment of the minority shareholders (Anderson et al., 2009; Chrisman et al., 2004; Salvato \& Moores, 2010). This entrenchment effect brought about by owners 
and managers may lead to a higher level of earnings management. Therefore, these two types of agency problem might determine the extent of earnings management in family firms.

The Socio-emotional wealth theory (SEW theory) theory asserts that the protection and the improvement of the utility gained from the non-economic aspects of the business is one of the leading objectives of the family owners when making decisions (Gómez-Mejía et al., 2011; Gómez-Mejía et al., 2007). These noneconomic aspects -such as maintaining family control and influence, financial independence of the firm, identification of family members with the firm, and the transfer of the firm to the next generation- are defined as the socio-emotional wealth of the family member (Gómez-Mejía et al., 2007). In other words, SEW generally refers to the "non-financial affect-related value" that a family acquires from its position of control and influence in order to pass it on to the next generation (Berrone et al., 2012). Indeed, this conjecture is found in Chua et al. (1999) and Schulze et al. (2003a) who consider that one main characteristic distinguishing family firms is that family members exercise control over strategic decisions. The 'Family control and influence' constitute an influential dimension of SEW, and it refers to a strong desire by family members to maintain influence and control over the business (Berrone et al., 2012).

Families can directly exercise control through occupying posts of chief executive officer (CEO) or chairman of the board, or more via appointing the top management team (TMT) members (Gómez-Mejía et al., 2011). As a consequence, the strategic decisions of family companies using "control and influence" as the main important dimension of SEW will generally be guided by the desire to keep family control over the business regardless of the economic considerations (Gómez-Mejía et al., 2007). Hence, so as to ensure and perpetuate the control and influence among the business, can be a spur for engaging in earnings management. Indeed, family owners emphasizing the control aspects of SEW are interested in avoiding the presence of any sources of financing which may affect their control position (Gómez-Mejía et al., 2010). As a consequence, for keeping their control position and influence over the firm, family owners will be more likely to engage in earnings management to avoid violation of the restrictive clauses of debt contracts (Prencipe et al., 2008). Similarly, family owners who emphasize the control and influence dimension of SEW are under increasing pressure to reach or exceed the specified result threshold. Several studies have shown that the publication of a negative result has harmful effects on the perception of the financial market, the stock market price and the cost of debt (Brown \& Caylor, 2005). This could lead investors to question the family's dominant position in the business, undermining the perpetuation of its control and influence. Accordingly, they will opt for earnings management to reach the earnings benchmark. 
For other family owners, however, the "Renewal of family bonds to the firm through dynastic succession" dimension of SEW is considered as highly salient. This dimension refers to the intention of transmitting the business to future generations (Berrone et al., 2012). As a matter of the fact, some studies have shown that maintaining the business for the next generation is commonly considered as a main objective for family owners (Miller \& Le Breton-Miller, 2006). When the trans-generational sustainability is more substantial, family members will be more likely to avoid any strategic decision having a negative effect on the future performance and future earnings of the firm (Achleitner et al., 2014). Regarding the relation between family ownership and earnings management, this dimension of SEW would reveal that family owners are less likely to engage in earning-management actions because of their negative consequences on future-accounting decisions, earnings and performance (Graham et al., 2005; Gunny, 2005; Jensen, 2005; McVay, 2006; Rodriguez-Ariza et al., 2016).

In short, the effect of family ownership on earnings management varies in accordance with the preferences of family owners who either keep control and influence or bequeath the business for future generations. In the subsequent section, we will develop our argument about family ownership having an impact on earnings management. This effect is derived from two perspectives: agency theory and SEW preservation.

\subsection{Earnings management in family firms: Research hypothesis}

There is existing literature showing contradictory results with respect to financial information quality of family firms. One axis of research based on US firms affirms that family businesses have better quality of financial information, and they are less engaged in earnings management practices than non-family ones (Ali et al., 2007; Jiraporn \& DaDalt, 2009; Martin et al., 2016; Wang, 2006). Similar findings have been found in studies based on German and Italian firms (Achleitner et al., 2014; Cascino et al., 2010; Prencipe \& Bar-Yosef, 2011). These studies have put to the proof that family firms face less serious Type I agency problems arising between managers and shareowners than non-family firms as a family represents the majority shareholders, and since it takes part in the management of the firm. These facts justify a better quality of financial and accounting information.

The SEW theory evinces that in family firms, the major concern of family owners is to safeguard the usefulness it gains from the business non-economic aspects (Gómez-Mejía et al., 2007). These aspects include, among others, the identification of family members with the firm, the enhancement of the family's ability to exercise control, and the preservation of the family dynasty to future generations (Berrone et al., 2012; Gómez-Mejía et al., 2010). Based on the trans-generational sustainability dimension of SEW theory, Achleitner et al. (2014) provided evidence 
that in order to maintain and preserve the wealth over time, family firms in Germany have to avoid REM inhibiting the firm's long-term value, and to engage in downward accrual-earnings management helping families retain transgenerational control. In the same vein, using a sample of listed firms in Japan, Chen et al. (2015) showed that the magnitude of income decrease using accrualbased strategies is greater for family firms compared to non-family ones, and they found that REM is lower for family firms compared to non-family ones. These authors came up with the idea that a founding family cared about the reputation of its company for supporting SEW, and family firms have fewer type I agency problems.

As noted above, when the trans-generational sustainability of the business is the reference dimension of SEW theory, family owners are predicted to avoid actions having a negative impact on future accounting decisions, earnings and performance (Graham et al., 2005; Gunny, 2005; Jensen, 2005; McVay, 2006; Rodriguez-Ariza et al., 2016). Furthermore, family firms are characterized by a concentrated ownership, and they are managed by multiple family members (Paiva et al., 2016), reducing the traditional owner-manager conflicts (Type I agency problem). These arguments lead family firms to be less likely to engage in income-increasing earnings management practices (ABEM and REM).

However, high levels of ownership concentration, and the collusion between ownership and management increase the opportunity for controlling family shareholders to expropriate minorities in family firms. Thus, the agency problem shifts from the traditional owner-manager conflicts (Type I agency problem) to one of majority-minority shareholders (Type II agency problem) (Faccio et al., 2001; La Porta et al., 2000). In this case, more recent studies have found a higher level of earnings management in family firms when compared with non-family ones. Chi et al. (2015) examine the relation between family ownership and earnings management in Taiwan. They remark that there is a higher level of discretionary accruals in family firms when compared to non-family ones. In the same context, Tai (2017) confirms the result found by Chi et al. (2015).

In a comparative study, Eng et al. (2019) looked into the difference in REM between US family firms and Chinese family ones. They substantiated that there is greater REM in family firms than in non-family ones in both countries. Moreover, they measured the dissimilarity of REM between Chinese and U.S. family corporations following the 2008 financial crisis, and showed that REM is greater in the US post-financial crisis, but it's lower in Chinese family firms in the postfinancial crisis. Hence, they noted that family firms face more serious type II agency conflict, and that the level of REM may be affected by the institutional context. Thus, controlling shareholders can easily expropriate wealth from minority investors in less developed institutions where investor protection laws are poor. 
Although the 'Family control and influence' is an important dimension of SEW (Berrone et al., 2012), the strategic decisions of family owners will be based on the desire to maintain family control regardless of the economic considerations (Gómez-Mejía et al., 2007). Thus, keeping and perpetuating the control and influence can be a motivation to engage in earnings management (Gómez-Mejía et al., 2014).

While the ownership structure of family firms enables controlling shareholders to manipulate earnings for personal benefits (Fan \& Wong, 2002; Leuz et al., 2003; Shleifer \& Vishny, 1997), and taking into account the family control and influence dimension of SEW, we expect that family owners have greater incentives to engage in upward earnings management.

Resting on the reasoning mentioned above, we establish two alternative hypotheses. Considering the less serious Type I agency problems in family firms because of the close relationship between management and owners and due to the desire to bequeath the business to the future generation (as a key dimension of SEW), we propose that family owners have more incentives to avoid upward earnings management decreasing the firm's value. As an alternative hypothesis, we expect that family firms to be more likely to better manage their results. Therefore, our hypothesis is:

Family ownership has a negative and significant effect on upward earnings management.

If the alternative hypothesis is supported, the cause may be the entrenchment effect by owners and manager, so this collusion can lead to another type of agency conflict that occurs between majority and minority shareholders (type II agency problem) (Faccio et al., 2001; La Porta et al., 2000). On this account, for same family owners, "Family control and influence" dimension of SEW is perceived as highly important, so it could be a stimulus for involving in earnings management (Gómez-Mejía et al., 2014; Prencipe et al., 2008).

\section{Methodology}

\subsection{Sample}

In order to test our hypothesis, our sample includes French companies listed on the CAC All-Tradable over the fiscal years through the 2014 to 2016 sample period. Our initial sample includes 306 listed companies on CAC All-Tradable. We reject financial activities (banks, and insurance companies) since they are governed by specific regulations, and because they have unique operating characteristics, so they are not comparable to non-financial firms. For these reasons, we exclude listed firms whose reference documents are not available online during the data collection period. Furthermore, the methodology for the estimation of earnings 
management proxies requires at least 15 observations for each 2-digit SIC grouping per year (Cohen \& Zarowin, 2010; Roychowdhury, 2006), which further reduces the sample. As a result of some missing values for the control variables, the final sample consists of 729 firm-year observations.

Financial data are collected from DataStream database. Due to lack of an electronic database of ownership information, the data are hand-collected from annual reports and reference documents. Aiming to identify family firms, we have referred to the criteria defined by Astrachan and Kolenko (1994), and used thereafter by Ali et al. (2007) and Beldi et al. (2014), i.e. companies whose capital held by the same family is more than $50 \%$ for unlisted companies, and $10 \%$ for listed companies, or one or more members of the family is present in the management or those have transmitted the business to future generations.

Based on these criteria, we have defined family firms as companies in which aggregate ownership held by family members is at least $10 \%$ of total shares, and one or more directors on the board are from the same family (Beldi et al., 2014). Counting on this definition, we generate a sample of 254 family firms' observations and 475 non-family firms' ones (see table 1).

Table 1. Distribution of family firms and non-family firms

\begin{tabular}{cccccc}
\hline \multirow{2}{*}{ Year } & $\begin{array}{c}\text { Number of firms } \\
\text { (family firms and } \\
\text { non-family ones) }\end{array}$ & \multicolumn{2}{c}{ Family firms } & \multicolumn{2}{c}{ Non-family firms } \\
\cline { 3 - 6 } & 237 & Number & Percentage & Number & Percentage \\
\hline $\mathbf{2 0 1 4}$ & 247 & 85 & $35.44 \%$ & 153 & $64.55 \%$ \\
\hline $\mathbf{2 0 1 5}$ & 245 & 85 & $34.41 \%$ & 162 & $65.58 \%$ \\
\hline $\mathbf{2 0 1 6}$ & 729 & 254 & $34.84 \%$ & 475 & $65.15 \%$ \\
\hline Total & & & & & \\
\hline
\end{tabular}

\subsection{Variables}

\subsubsection{Dependent variables}

In this study, we have adopted two measures of earnings management: discretionary accruals and real earnings management.

Measurement of accrual-based earnings management (ABEM): We use the abnormal discretionary accruals as a proxy for the extent of (upward) accrualearnings management. Several methods are adopted to estimate discretionary accruals. According to Bartov et al. (2000), the modified Jones model provides the best estimates of discretionary accruals. 
Thus, "ABEM" is estimated, using the modified Jones model on a cross-sectional basis as in Dechow et al. (1995). The estimation model of abnormal accruals is described as follows:

$$
\begin{aligned}
\mathbf{T A C}_{\mathrm{i}, \mathrm{t}} / \mathbf{A T}_{\mathrm{i}, \mathrm{t}-1} & =\alpha_{0}+\alpha_{1}\left(1 / \mathbf{A T}_{\mathrm{i}, \mathrm{t}-1}\right)+\alpha_{2}\left(\left(\Delta \operatorname{Rev}_{\mathrm{i}, \mathrm{t}}-\Delta \mathbf{R e c}_{\mathrm{i}, \mathrm{t}}\right) / \mathbf{A T}_{\mathrm{i}, \mathrm{t}-\mathbf{1}}\right) \\
& +\alpha_{3}\left(\mathrm{PPE}_{\mathrm{i}, \mathrm{t}} / \mathrm{AT}_{i, t-1}\right)+\varepsilon_{\mathrm{i}, \mathrm{t}}
\end{aligned}
$$

where $\mathrm{TAC}_{\mathrm{i}, \mathrm{t}}$ : Total accruals of firm $\mathrm{i}$ in year $\mathrm{t}, \mathrm{AT}_{\mathrm{i}, \mathrm{t}-1}$ : Total assets of firm $\mathrm{i}$ at the beginning of year $t-1, \Delta \operatorname{Rev}_{i t}$ : Change in revenues of firm $i$ in year $t, \Delta \operatorname{Rec}_{i, t}$ : Change in receivable accounts of firm $i$ in year $t, \mathrm{PPE}_{\mathrm{i}, \mathrm{t}}$ : Gross property, plant and equipment of firm $i$ in year $t$. Discretionary accruals are obtained by the difference between total accruals and non-discretionary accruals.

Since we predict that family ownership has a negative impact on upward earnings management, the earnings management is directional. Thus, our research design should focus attention on the raw value of discretionary accruals (Larcker \& Richardson, 2004).

Measurement of real earnings management (REM): Following Roychowdhury (2006), we consider three proxies: the abnormal cash flows from operations (AbCfo), the abnormal discretionary expenses (AbDisc), and the abnormal production costs (AbProd). These measures have been used by other researchers (Cohen et al., 2008; Cohen \& Zarowin, 2010).

Abnormal cash flows from operations "AbCfo": Managers can accelerate sales from the following year to the current year, by offering price reductions or more flexible credit terms. This, therefore, increases the profits for the current financial year while it may result in lower cash-flows from operation for the same level of sales. Indeed, managers are ready to sacrifice future profits to make additional sales in the current period (Roychowdhury, 2006). Hence, cash flows from operations (CFO) which are abnormally lower than the normal level is interpreted as evidence of earnings-increasing REM. To estimate the normal level of CFO, we use the following model:

$$
\begin{aligned}
\mathrm{CFO}_{\mathrm{i}, \mathrm{t}} / \mathrm{AT}_{\mathrm{i}, \mathrm{t}-\mathrm{1}} & =\alpha_{0}+\alpha_{1}\left(1 / \mathbf{A T}_{\mathrm{i}, \mathrm{t}-1}\right)+\alpha_{2}\left(\operatorname{Sales}_{\mathrm{i}, \mathrm{t}} / \mathrm{AT}_{\mathrm{i}, \mathrm{t}-1}\right) \\
& +\alpha_{3}\left(\Delta \operatorname{Sales}_{\mathrm{i}, \mathrm{t}} / \mathrm{AT}_{\mathrm{i}, \mathrm{t}-1}\right)+\varepsilon_{\mathrm{i}, \mathrm{t}}
\end{aligned}
$$


where $\mathrm{CFO}_{\mathrm{i}, \mathrm{t}}$ : Cash-flows from operations of firm $\mathrm{i}$ in year $\mathrm{t} ; \mathrm{AT}_{\mathrm{i}, \mathrm{t}-1}$ : Total assets of firm $i$ at the beginning of year $\mathrm{t}-1$; Sales $_{\mathrm{i}, \mathrm{t}}$ : Net Sales of firm $i$ in year $\mathrm{t} ; \Delta \operatorname{Sales}_{\mathrm{i}, \mathrm{t}}$ : Change in Sales of firm i in year t.

Abnormal cash flows are obtained by the difference between the total cash flows from operations and the normal level of cash flows (non-discretionary).

Abnormal discretionary expenses "AbDisc": Managers can increase profits for the current fiscal year by reducing expenses related to investing activities such as research and development expenses (R\&D), general and administrative expenses and advertising expenses (SG\&A). Negative values of abnormal discretionary expenses "AbDisc" are interpreted as evidence of earnings-increasing REM. As a result, the normal level of discretionary expenses will be estimated, using the Roychowdhury (2006) following model:

$$
\operatorname{DISDEP}_{\mathrm{i}, \mathrm{t}} / \mathrm{AT}_{\mathrm{i}, \mathrm{t}-1}=\alpha_{0}+\alpha_{1}\left(1 / \mathbf{A T}_{\mathrm{i}, \mathrm{t}-1}\right)+\alpha_{2}\left(\operatorname{Sales}_{\mathrm{i}, \mathrm{t}-1} / \mathbf{A T}_{\mathrm{i}, \mathrm{t}-1}\right)+\varepsilon_{\mathrm{i}, \mathrm{t}}
$$

where DISDEP $\mathrm{i}_{\mathrm{i}, \mathrm{t}}$ : discretionary expenses of firm $\mathrm{i}$ in the period $\mathrm{t} ; ; \mathrm{AT}_{\mathrm{i}, \mathrm{t}-1}$ : Total assets of firm $\mathrm{i}$ at the beginning of year $\mathrm{t}-1$; Sales $_{\mathrm{i}, \mathrm{t}-1}$ : Net Sales of firm i in year $\mathrm{t}$ 1. The AbDisc is set equal to actual discretionary expenses minus normal level of discretionary expenses.

Abnormal production costs "AbProd": Manager can overproduce to reduce the costs of products sold (COGS). As a result, they spread fixed costs over a larger number of production units. Thus, the cost of production per unit decreases, resulting in increase in earnings. Therefore, an abnormal increase in production costs is interpreted as an upward earnings management. Production costs are defined as the sum of costs of goods sold (COGS) at time $t$ and the change in inventories $(\triangle \mathrm{INV})$. The normal level of PROD is estimated with the following model (Roychowdhury, 2006):

$$
\begin{aligned}
\operatorname{PROD}_{\mathrm{i}, \mathrm{t}} / \mathbf{A T}_{\mathrm{i}, \mathrm{t}-1} & \\
= & \alpha_{0}+\alpha_{1}\left(1 / \mathbf{A T}_{\mathrm{i}, \mathrm{t}-1}\right)+\alpha_{2}\left(\operatorname{Sales}_{\mathrm{i}, \mathrm{t}} / \mathbf{A T}_{\mathrm{i}, \mathrm{t}-\mathbf{1}}\right) \\
& +\alpha_{3}\left(\Delta \operatorname{Sales}_{\mathrm{i}, \mathrm{t}} / \mathbf{A T}_{\mathrm{i}, \mathrm{t}-1}\right)+\alpha_{4}\left(\Delta \operatorname{Sales}_{\mathrm{i}, \mathrm{t}-\mathbf{1}} / \mathbf{A T}_{\mathrm{i}, \mathrm{t}-1}\right)+\varepsilon_{\mathrm{i}, \mathrm{t}}
\end{aligned}
$$

where $\mathrm{PROD}_{\mathrm{i}, \mathrm{t}}$ : production costs of firm $\mathrm{i}$ at time $\mathrm{t}$; and all other variables are as previously defined. The AbProd is the difference between actual PROD and the expected normal level. 
Following foregoing researches (Cohen et al., 2008; Roychowdhury, 2006), we construct an overall summary measure of REM (REM_AGG), using the sum of the three standardized REM metrics ( - AbCfo - AbDisc + AbProd), so that greater values of REM_AGG imply higher levels of REM.

\subsubsection{Independent and control variables}

We investigate earnings management in the French family firms, and hence our independent variable is family ownership. A firm is classified as a family firm (FF) if the aggregate ownership held by family members is at least $10 \%$ of total shares, and one or more directors on the board are from the same family (Ali et al., 2007, Beldi et al., 2014). Thus, "FF" is a binary variable which is set equal to one if a firm is classified as a family firm, and zero, otherwise. We use this variable because it is adopted by a large number of studies on the family business (Beldi et al., 2014; Cascino et al., 2010; Chen \& Jaggi, 2000), and it allows us to take into account not only the percentage of shares owned by family, but also the presence of the family members in a governing body.

In our regression analysis testing, we also control other factors possibly having an effect on the level of earnings management. Following preceding studies, we control firm size (SIZE) defined as the natural logarithm of total assets at the end of the period (Becker et al., 1998; Cormier et al., 1998). The political cost hypothesis evinces that the higher the political costs to the company (e.g., taxes or costs incurred by government or industry regulations) are, the more likely the management is to make income-decreasing accounting choices so as to reduce the size or the probability of wealth transfers politically imposed (Watts \& Zimmerman, 1978).

Furthermore, leverage (LEV) is included. It is measured by the proportion of total debts to total assets. The debt covenant hypothesis states that after debt contracts have been negotiated, firms have incentives to make upward earnings management for the purpose of avoiding the violation of covenants in their debt agreements (Beneish \& Press, 1993).

We also include the profitability (return on assets ratio (ROA)) in our models so that we can control the impact of firm-operating performance on earnings management. Hence, "ROA" is measured by the ratio of operating income to total assets (Aslam et al., 2016; Chavali \& Rosario, 2018). Several studies find evidence consistent with earnings management being positively associated with the manager's expectation of future performance (DeFond \& Park, 1997; Jennifer et al., 2005; Subramanyam, 1996). 
In addition, we control the firm-specific risk of bankruptcy (Burgstahler \& Dichev, 1997, Degeorge et al., 1999). Thus, "LOSS" is a dummy variable taking the value one if net income is less than zero, and zero, otherwise (Achleitner et al., 2014; Embong \& Hosseini, 2018; Razzaque et al., 2016).

Moreover, some previous studies have reported that high levels of growth opportunities may encourage managers to engage in earnings management practices (Becker et al., 1998; Roychowdhury, 2006). We then include "Growth" measured by the sales growth rate for the current period (Chi et al., 2015; Malik \& Ahmad, 2017).

Lastly, we control the age of the firm. Various researches give proof that old firms might improve their reputation and image (Akhtaruddin, 2005), and enhance their financial reporting practices over time (Alsaeed, 2006). Old firms might also have a sounder governance mechanism, and so a low agency costs (Chu, 2009). Therefore, the older the firms are, the less likely they are to engage in earnings management practices. "FirmAge" has been measured as natural logarithm of total years since the firms were founded (Bassiouny et al., 2016; Jara-Bertin \& Sepulveda, 2016).

Table 2. Description and measurement variables

\begin{tabular}{|c|c|c|}
\hline Variables & Definition & Measure \\
\hline \multicolumn{3}{|c|}{ Dependent variables } \\
\hline ABEM & $\begin{array}{l}\text { Abnormal } \\
\text { discretionary } \\
\text { Accruals }\end{array}$ & the modified Jones model (Dechow et al., 1995) \\
\hline REM-AGG & $\begin{array}{l}\text { Aggregate } \\
\text { REM measures }\end{array}$ & $\begin{array}{l}\text { Following Roychowdhury (2006), REM_AGG is the } \\
\text { sum of three standardized REM metrics }\end{array}$ \\
\hline \multicolumn{3}{|c|}{ Independent variables } \\
\hline FF & Family Firm & $\begin{array}{l}\text { Binary variable which equals one if a firm is classified } \\
\text { as family firm, and zero, otherwise (Ali et al., 2007; } \\
\text { Beldi et al., 2014) }\end{array}$ \\
\hline SIZE & Firm size & $\begin{array}{l}\text { The natural logarithm of total assets at the end of the } \\
\text { period (Becker } \text { et al., 1998; Cormier } \text { et al., 1998). }\end{array}$ \\
\hline LEV & $\begin{array}{l}\text { Leverage of the } \\
\text { firm }\end{array}$ & $\begin{array}{l}\text { The proportion of total debts to total assets (Achleitner } \\
\text { et al., 2014). }\end{array}$ \\
\hline ROA & $\begin{array}{l}\text { Firm operating } \\
\text { performance }\end{array}$ & $\begin{array}{l}\text { The ratio of operating income to total assets (Aslam } e t \\
\text { al., 2016; Chavali \& Rosario, 2018). }\end{array}$ \\
\hline LOSS & $\begin{array}{l}\text { Financial } \\
\text { distress }\end{array}$ & $\begin{array}{l}\text { Dummy variable, coded one if net incomes is less than } \\
\text { zero, and zero, otherwise (Achleitner et al., 2014; } \\
\text { Embong \& Hosseini, 2018; Razzaque } \text { et al., 2016). }\end{array}$ \\
\hline Growth & $\begin{array}{l}\text { The growth } \\
\text { opportunities }\end{array}$ & $\begin{array}{l}\text { The sales growth rate for the current period (Chi et al., } \\
\text { 2015; Malik \& Ahmad, 2017). }\end{array}$ \\
\hline FirmAge & $\begin{array}{l}\text { The age of the } \\
\text { firm }\end{array}$ & $\begin{array}{l}\text { The natural logarithm of total years since the firm is } \\
\text { founded (Bassiouny et al., 2016; Jara-Bertin \& } \\
\text { Sepulveda, 2016). }\end{array}$ \\
\hline
\end{tabular}

Vol. 19, No. 2 


\subsubsection{The Regression Models}

In the current paper, we explore both accrual-based earnings management (ABEM) and real activity-based earnings management (REM). Thus, intending to test our hypothesis, our models are as follows:

$$
\begin{aligned}
& \text { Model } 1 \text { ABEM }_{\text {it }}=\alpha_{0}+\alpha_{1} \text { FF F }_{\text {it }}+\alpha_{2} \text { SIZE }_{\text {it }}+\alpha_{3} \text { LEV }_{\text {it }}+\alpha_{4} \text { ROA }_{\text {it }}+ \\
& \alpha_{5} \text { LOSS }_{\text {it }}+\alpha_{6} \text { Grwoth }_{\text {it }}+\alpha_{7} \text { FirmAge }_{\text {it }}+\varepsilon_{\text {it }},
\end{aligned}
$$

where $A B E M_{i t}$ : abnormal discretionary accruals; $\mathrm{FF}_{\mathrm{it}}$ : dummy variable coded one if a firm is a family one, and zero, otherwise; SIZE $_{\text {it }}$ : the natural logarithm of total assets at the end of the period; $\mathrm{LEV}_{\mathrm{it}}$ : the proportion of long-term debts to total assets; $\mathrm{ROA}_{\mathrm{it}}$ : the ratio of operating income to total assets; $\mathrm{LOSS}_{\mathrm{it}}$ : dummy variable coded one if net income is less than zero, and zero, otherwise; Grwoth $\mathrm{it}_{\mathrm{it}}$ : the sales growth rate for the current period; FirmAge ${ }_{i t}$ : the natural logarithm of total years since the firm is founded.

$$
\begin{aligned}
& \text { Model } 2 \text { REM_AGG } \\
& \alpha_{5} \text { LOSS }_{\text {it }}+\alpha_{6} \text { Grwoth }_{\text {it }}+\alpha_{7} \text { FirmAge }_{\text {it }}+\alpha_{1} \text { FF }_{\text {it }}+\alpha_{2} \text { SIZE }_{\text {it }}+\alpha_{3} \text { LEV }_{\text {it }}+\alpha_{4} \text { ROA }_{\text {it }}+
\end{aligned}
$$

where REM_AGG ${ }_{\mathrm{it}}$ : real earnings management measured by the aggregate REM measure; and all other variables are as previously defined.

\section{Results}

\subsection{Descriptive Statistics}

Table 3 exhibits the descriptive statistics of the quantitative variables in the overall sample, and table 4 displays the number and the percentage of dummy variables in the pooled sample. For table 5, it presents the descriptive statistics of the dependent variables in the two sub-samples (Family Firm and Non-Family Firm).

The mean of the discretionary accruals is negative, which means that most companies manipulate the discretionary accruals downward with the aim of reducing earnings. Moreover, table 5 shows that discretionary accruals are more important (in terms of absolute value) for family firms than for non-family ones ( $\mid$ $0.007|>| 0.012 \mid$ ). Additionally, table 5 points out a positive mean of REM_AGG in family firms (0.016) and a negative one of REM_AGG in non-family firms (0.009). This indicates that, on average, the REM_AGG is more important for family companies than for non-family ones $(|0.016|>\mid-0.009)$. This result is consistent with (Razzaque et al., 2016). 
The result of Mann-Whitney test about mean comparisons of variables between the two groups of firms displayed in Table 5 confirms the significance difference of means between the two groups of two variables: ABEM and REM_AGG. The level of ABEM is different at $10 \%$ level between family and non-family firms, and the level of REM_AGG is significant at 5\% level. These results provide initial proof that the amount of earnings management (ABEM and REM) in family firms is greater than that of earnings management in non-family ones.

Table 3. Descriptive Statistics for pooled sample ( $N=729)$

\begin{tabular}{ccccc}
\hline Variables & Mean & Std.Dev. & Min & Max \\
\hline ABEM & -0.0004 & 0.1566 & -2.2721 & 1.1588 \\
\hline REM_AGG & -0.0005 & 0.3994 & -2.7921 & 3.1707 \\
\hline SIZE & 13.4111 & 2.4682 & 7.9582 & 19.4503 \\
\hline LEV & 0.2213 & 0.2259 & 0 & 3.8125 \\
\hline ROA & -0.0049 & 0.1986 & -1.8738 & 0.6724 \\
\hline Growth & 0.6378 & 4.9644 & -17.8309 & 82.2631 \\
\hline FirmAge & 3.5282 & 0.8688 & 0 & 5.7462 \\
\hline
\end{tabular}

Table 4. Descriptive Statistics of dummy variable

\begin{tabular}{cccccccc}
\multirow{2}{*}{ Variables } & Modality & \multicolumn{3}{c}{ Number } & \multicolumn{3}{c}{ Percentage } \\
\cline { 2 - 8 } & & $\mathbf{2 0 1 4}$ & $\mathbf{2 0 1 5}$ & $\mathbf{2 0 1 6}$ & $\mathbf{2 0 1 4}$ & $\mathbf{2 0 1 5}$ & $\mathbf{2 0 1 6}$ \\
\hline \multirow{2}{*}{ LOSS } & 1 & 64 & 70 & 68 & $27.00 \%$ & $28.34 \%$ & $27.75 \%$ \\
\cline { 2 - 8 } & 0 & 173 & 177 & 177 & $93.00 \%$ & $71.66 \%$ & $72.25 \%$ \\
\hline Total & & 237 & 247 & 245 & $100 \%$ & $100 \%$ & $100 \%$ \\
\hline
\end{tabular}

Table 5. Descriptive Statistics of dependent variables for two subsamples (Family Firm and Non-Family Firm)

\begin{tabular}{lccccccccc}
\hline & \multicolumn{3}{c}{$\begin{array}{c}\text { Non-Family firms } \\
(\mathrm{n}=475)\end{array}$} & \multicolumn{3}{c}{$\begin{array}{c}\text { Family firms } \\
(\mathrm{n}=254)\end{array}$} & \multicolumn{2}{c}{$\begin{array}{c}\text { Difference } \\
\text { mean }\end{array}$} \\
\hline Variables & Mean & Std.Dev & Min & Max & Mean & Std.Dev & Min & Max & z-test \\
\hline ABEM & -0.0073 & 0.1551 & -2.2721 & 0.4262 & 0.0124 & 0.1588 & -1.9933 & 1.1588 & $-1.742^{*}$ \\
& & & & & & & & $(0.0816)$ \\
\hline REM_AGG -0.0096 & 0.4250 & -2.7921 & 3.1707 & 0.0163 & 0.3467 & -1.2292 & 0.7536 & $-1.973 * *$ \\
& & & & & & & & $0.0485)$ \\
\hline
\end{tabular}

* Significant at $10 \%, * *$ significant at $5 \%, * * *$ significant at $1 \%$ 


\subsection{Correlation matrix}

Table 6 reports the Pearson correlation matrix between independent variables. The matrix should not exceed 0,8 to evince that multicollinearity does not constitute a major concern (Gujarati, 2003). As shown in table 6, we have realized that there is no serious correlation problem between variables.

Table 6. Pearson correlation between independent variables

\begin{tabular}{lccccccc}
\hline & FF & SIZE & LEV & ROA & LOSS & Growth & FirmAge \\
\hline FF & 1.000 & & & & & & \\
SIZE & 0.026 & 1.000 & & & & & \\
LEV & -0.063 & 0.146 & 1.000 & & & & \\
ROA & 0.212 & 0.412 & 0.034 & 1.000 & & & \\
LOSS & -0.253 & -0.392 & 0.006 & -0.604 & 1.000 & & \\
Growth & -0.103 & -0.162 & -0.034 & -0.359 & 0.237 & 1.000 & \\
FirmAge & 0.270 & 0.318 & 0.082 & 0.345 & -0.330 & -0.162 & 1.000 \\
\hline
\end{tabular}

\subsection{Regression Results}

In this section, we present and discuss the results of the regression attempting to analyze the effect of family ownership on earnings management. In order to decide on the homogeneity or heterogeneity of the panel data, we run a specification panel test. Then, we address the tests for the heteroscedasticity and the serial correlation of error terms. We adopts the Generalized Least Squared (GLS) technique correcting heteroskedasticity and serial correlation problems related to panel data (Ouellet et al., 2005). The results are displayed in Table 7. The Wald Chi2 tests are significant at $1 \%$ level for two models.

As shown in Table 7, the results drawn from regression (model 1) suggest that the variable "FF" has no significant effect on ABEM, so our hypothesis is not supported. Unlike our results from the test for comparing means, evidence in this table reports that the family ownership has no significant effect on the ABEM. This result contradicts those found by a number of authors like Achleitner et al. (2014), Cascino et al. (2010), and Chi et al. (2015).

The result in table 7 points that the coefficient estimates on "FF" is positive and significant at $1 \%$ level in model 2 (coefficient $=0.053$; $\mathrm{p}$-value $=0.000)$. Overall, we find that family firms in France engage more in REM than non-family ones. Our alternative hypothesis is accepted. This result reinforces those of Eng et al. (2019) for US and Chinese family firms, and Razzaque et al. (2016) for Bangladeshi family firms. This provides three proofs (1) family firms face more serious type II agency problems arising from the conflict between the majority and the minority shareholders (Ali et al., 2007, Anderson et al., 2009). Controlling 
shareholders (family owners) have incentives to expropriate minority shareholders in order to appropriate their private benefits; (2) despite the fact that REM may have a negative consequence on the firm's future value (Gunny, 2005), family owners emphasizing the control aspects of SEW engage more in REM to keep control and influence over the business regardless of economic outcomes; and (3) the desire to maintain control among firms can deepen the agency problems between family owners (majority shareholders) and other shareholders. As a consequence, family firms are more engaged in earnings management practices than non-family ones.

To summarize, we can draw two main conclusions. Firstly, family firms in France are more engaged in earnings management practices. This result provides evidence that family firms suffer from the type II agency problem. What is more, it gives proof that for family owners -taking into account the 'Family control and influence' dimension of SEW as more substantial reference point than the 'transgenerational sustainability' dimension- manage their earnings regardless of the impacts that could be created. Accordingly, the desire to maintain control and influence among firms deepens the agency problems between family owners (majority shareholders) and other shareholders (minority shareholders).Secondly, family owners use real activities to manipulate earnings. This can be explained as follows: to begin with, as accrual manipulations are often held at the end of the fiscal year, REM may occur at any time of the year. Besides, from a managerial perspective, REM activities are more flexible and easier for family firms because family owners are often an executive directors in the firms (Anderson et al., 2003), so they may enjoy greater latitude in altering real activities. Finally, ABEM can be easily detected by auditors, regulators and independent directors (Klein, 2002; Zang, 2011) whereas REM is less likely to be detected and distinguished for other economic transactions of the company.

Touching the control variables, the table below indicates that "SIZE" has a negative and significant impact on ABEM, but it has a positive and significant effect on REM_AGG. Managers in large companies are more likely to limit upward accrual-earnings management (Watts \& Zimmerman, 1978), but they opt for the REM. Hence, large firms have more incentives to engage in earnings management. They do it via real activities because it is difficult to detect. Table 7 indicates that "LEV" has a negative and significant effect on ABEM. This confirms the results found by Fung and Goodwin (2013) and Jelinek (2007). They noted that creditors might make more monitoring costs to assess the quality of accounting information. Thus, indebtedness is a control mechanism limiting the opportunistic behavior of managers (Jensen, 1986).

Our results show that the profitability has a significant effect on earnings management. Table 7 displays a significant positive and negative coefficient of the ROA variable on discretionary accruals and actual management, respectively. This 
result is found by Achleitner et al. (2014). Performing companies have a high level of discretionary accruals, and they are less likely to manipulate real activities. Moreover, the significant effect of "LOSS" variable suggests that financial distress constitutes a motivation to manipulate earnings. Although accrual-earnings management can be easily detected by the regulators and auditors to avoid loss, firms engage more in REM than in ABEM. Firm age is found to have a positive relationship with both ABEM and REM. This result suggests that mature firms are more likely to use earnings management than immature ones (Debnath, 2017; Wu \& Huang, 2011).

Table 7. Regression Results

\begin{tabular}{lccccc}
\hline \multirow{2}{*}{ Variables } & \multirow{2}{*}{$\begin{array}{c}\text { Predicted } \\
\text { sign }\end{array}$} & \multicolumn{2}{c}{ Model 1 : ABEM } & \multicolumn{2}{c}{ Modele2 : REM_AGG } \\
\cline { 2 - 6 } & coefficients & $\mathrm{P}>|\mathrm{Z}|$ & coefficients & $\mathrm{P}>|\mathrm{Z}|$ \\
\hline FF & $+/-$ & -0.0027 & 0.224 & 0.0531 & $0.000^{* * *}$ \\
SIZE & - & -0.0040 & $0.000^{* * *}$ & 0.0041 & $0.018^{* *}$ \\
LEV & + & -0.0652 & $0.000^{* * *}$ & -0.0198 & 0.449 \\
ROA & + & 0.0383 & $0.002^{* * *}$ & -0.4837 & $0.000^{* * * *}$ \\
LOSS & + & -0.0419 & $0.000^{* * *}$ & 0.0359 & $0.014^{* *}$ \\
Growth & $+/-$ & -0.0008 & 0.151 & 0.0002 & 0.934 \\
FirmAge & - & 0.0031 & $0.003^{* * *}$ & 0.0318 & $0.000^{* * *}$ \\
Constant & $+/-$ & 0.0737 & $0.000^{* * *}$ & -0.1841 & $0.000^{* * *}$ \\
$\mathbf{R}^{2}$ en \% & \multicolumn{7}{c}{13.14} & & 7.26 \\
Wald chi2(7) & \multicolumn{7}{c}{0.006 .94} & \multicolumn{2}{c}{0.0000} \\
Prob > chi2 & \multicolumn{7}{c}{729} \\
No of \\
observations
\end{tabular}

$*$ Significant at 10\%, ** significant at 5\%, *** significant at $1 \%$

\section{Discussion and contribution}

This paper aims to examine the impact of family ownership on two types of earnings management: ABEM and REM. To account for this relation, this research builds on two theories: agency theory and SEW theory. In an agency setting, family firms are characterized by the fact that classic agency problems are limited. However, concentrated ownership results in two distinct groups of shareholders, i.e., majority and minority shareholders. Consequently, it could bring about a new agency problem consisting in a conflict between the controlling family and minority shareholders (Type II agency problem). Controlling family has an opportunity to maximize their private benefits by expropriating minority shareholders. 
Furthermore, SEW theory states that the primary objective of family owners is to preserve and protect the utility arising from non-economic aspects of the firm (Gómez-Mejía et al., 2011; Gómez-Mejía et al., 2007). These non-economic aspects cover various forms such as enhancing the family's ability to exercise control and influence over the business, identity of family members, and family succession. Given the multi-dimensional nature of SEW (Berrone et al., 2012; Cennamo et al., 2012), Gómez-Mejía et al. (2014) argue that the accounting choices would be different among family firms, depending on their most important SEW dimensions. In this study, we focus on "Family control and influence" and the "the Renewal of family bonds to the firm through dynastic succession" dimensions that have been, for some recent studies, considered as the most prominent reference point (Gómez-Mejía et al., 2007, Strike et al., 2015). These two dimensions can differently explain the link between the family ownership and earnings management. For family firms using the 'Family Control and Influence' dimension of SEW as a main objective, maintaining control and influence over the business motivates them to engage in earnings management (Prencipe et al., 2008). However, for other family firms, "the trans-generational sustainability" is considered as a very important dimension of SEW (Berrone et al., 2012). Therefore, the manager in family firms is less likely to engage in activities having a negative effect on the future firm's value than the manager in non-family firms. Prior studies have proved that earnings management has a negative consequence on future accounting decisions, earnings and performance (Graham et al., 2005; Gunny, 2005; Jensen, 2005; McVay, 2006; Rodriguez-Ariza et al., 2016).

For family firms, earnings management can be explained by agency problems and the desire to preserve SEW endowment. SEW theory states that maintaining control and influence over the business and the intention for trans-generational sustainability are two important goals of family firms. Besides, we put emphasis on two alternative hypotheses. On the one hand, we predict that -as family firms are facing a less severe Type I agency problem, and family owners may give more importance to the trans-generational sustainability of their business- family firms are less likely to manage their results than non-family ones. On the other hand, we expect that -as the agency problem shifts from a manager-shareholder conflict to that of majority-minority shareholders, and for some family owners, the family control and influence is perceived as highly protruding (Berrone et al., 2012)family firms are more likely to engage in earnings management practices than nonfamily ones.

Using a sample of French firms listed in CAC All-Tradable index from 2014 to 2016, we first document, unlike our predictions, that family ownership has no significant effect on ABEM. Second, we provide evidence that family ownership has a positive and significant impact on REM_AGG. This result is consistent with Razzaque et al. (2016). Hence, in France, family firms are more engaged in REM than non-family ones. These findings confirm that family firms suffer from a new 
agency conflict between the minority shareholders and controlling owners (type II agency problem). Even through previous studies have indicated that REM has a negative impact on future cash flows and may reduce the firm's value as managers are willing to sacrifice future cash flows for higher current incomes (Gunny, 2005; Roychowdhury, 2006), family firms in France are more engaged in REM than nonfamily ones. This result gives proof that in French family firms, the control aspect of SEW theory is predominant regardless of financial considerations. Hence, the desire to maintain control and influence among firms reinforces the opportunistic behavior of family owners, and therefore, it worsens the agency problems between family owners (majority shareholders) and other shareholders (minority shareholders).

Moreover, we explain our findings as follows: REM can occur at any time of the year while accruals manipulations are usually carried out at the end of the fiscal year. Accordingly, REM are considered to be easier in family firms since family members participate in firms management (Anderson \& Reeb, 2003), and, therefore, they might have more leeway to change recurring operational and investment decisions. Furthermore, ABEM is more likely to be detected by stakeholders such as auditors, regulators and independent directors (Klein, 2002; Zang, 2011) than REM that is difficult to be distinguished from other economic transactions of the company.

Our study contributes to the debate on earnings quality in family firms in several ways. First, the issue of REM in family firms is not the subject of much research (Achleitner et al., 2014; Eng et al., 2019; Razzaque et al., 2016). Our study demonstrates two methods of earnings management: ABEM and REM_AGG. Second, most previous studies have been based on the agency theory to explain the relation between the family firm and earnings management. The current study also uses the SEW theory offering a more comprehensive framework to explain this relationship. SEW constitutes the major characteristic giving family firms their unique qualities, and driving their strategic decisions (Berrone et al., 2012; GómezMejía et al., 2010). Several empirical studies indicate how SEW foresees different strategic choices (Berrone et al., 2012; Gómez-Mejía et al., 2011; Gómez-Mejía et $a l ., 2010)$. Therefore, it is prominent to consider this non-economic goal to foresee and account for the earnings management in family firms. Third, this research gives evidence that for family firms, to preserve control and influence over the firm, they make income-increasing accounting choices at the expense of other objectives such as future performance. Eventually, the findings of our study add to the literature through providing empirical evidence that family owners are more engaged in REM than non-family ones of an institutional context characterized by poor investor protection.

This study suffers from some limitations which have to be pointed out. To start with, we have focused attention on listed firms, limiting the generalizability of our 
findings, especially with respect to private companies. In privately-held organizations, using REM might be exaggerated. Second, we have not investigated under what incentive structure family firms manipulate their earnings. Building on this research, future studies could investigate these factors over a long period of time. Finally, in this study, we have considered family firms as a homogeneous group, so it is worth addressing the heterogeneity among family firms (e.g. with regard to generational stage, CEO position), which is a scope for future research.

\section{References}

Achleitner, A.-K., Günther, N., Kaserer, C. \& Siciliano, G. (2014) "Real Earnings Management and Accrual-based Earnings Management in Family Firms", European Accounting Review, vol. 23, no. 3: 431-461

Akhtaruddin, M. (2005) "Corporate mandatory disclosure practices in Bangladesh", The International Journal of Accounting, vol. 40, no. 4: 399422

Ali, A., Chen, T.-Y. \& Radhakrishnan, S. (2007) "Corporate disclosures by family firms", Journal of Accounting and Economics, vol. 44, no. 1-2: 238-286

Alsaeed, K. (2006) "The association between firm-specific characteristics and disclosure: The case of Saudi Arabia", Managerial Auditing Journal, vol. 21, no. 5: 476-496

Anderson, M. C., Banker, R. D. \& Janakiraman, S. N. (2003) "Are selling, general, and administrative costs "sticky"?", Journal of Accounting Research, vol. 41, no. 1: 47-63

Anderson, R. C., Duru, A. \& Reeb, D. (2009) "Founders, heirs, and corporate opacity in the United States", Journal of Financial Economics, vol. 92, no. 2:

205-222

Anderson, R. C. \& Reeb, D. M. (2003) "Founding-Family Ownership and Firm Performance: Evidence from the S\&P 500", The journal of finance, vol. 58, no. 3: 1301-1328

Aslam, E., Ijaz, F. \& Iqbal, A. (2016) "Does Working Capital and Financial Structure Impact Profitability of Islamic and Conventional Banks Differently?", Islamic Banking and Finance Review, vol. 3, no. 01: 50-67

Astrachan, J. H. \& Kolenko, T. A. (1994) "A Neglected Factor Explaining Family Business Success: Human Resource Practices", Family Business Review, vol. 7, no. 3: 251-262

Bartov, E., Gul, F. \& Tsui, J. S. L. J. S. L. (2000) "Discretionary-accruals models and audit qualifications", Journal of Accounting and Economics, vol. 30, no. 3: 421-452

Bassiouny, S. W., Soliman, M. M. \& Ragab, A. (2016) "The impact of firm characteristics on earnings management: an empirical study on the listed firms in Egypt", The Business \& Management Review, vol. 7, no. 2: 91 
Becker, C. L., DeFond, M. L., Jiambalvo, J. \& Subramanyam, K. (1998) "The effect of audit quality on earnings management", Contemporary accounting research, vol. 15, no. 1: 1-24

Beldi, A., Damak-Ayadi, S. \& Elleuch, A. (2014) "La divulgation volontaire sur le capital intellectuel: cas des entreprises familiales et non familiales en France", Revue de l'Entrepreneuriat, vol. 13, no. 3: 99-121

Beneish, M. D. \& Press, E. (1993) "Costs of technical violation of accountingbased debt covenants", Accounting Review, 233-257

Berrone, P., Cruz, C. \& Gomez-Mejia, L. R. (2012) "Socioemotional Wealth in Family Firms:Theoretical Dimensions, Assessment Approaches, and Agenda for Future Research", Family Business Review, vol. 25, no. 3: 258-279

Berrone, P., Cruz, C., Gomez-Mejia, L. R. \& Larraza-Kintana, M. (2010) "Socioemotional Wealth and Corporate Responses to Institutional Pressures: Do Family-Controlled Firms Pollute Less?", Administrative Science Quarterly, vol. 55, no. 1: 82-113

Brown, L. D. \& Caylor, M. L. (2005) "A temporal analysis of quarterly earnings thresholds: Propensities and valuation consequences", The Accounting Review, vol. 80, no. 2: 423-440

Burgstahler, D. \& Dichev, I. (1997) "Earnings management to avoid earnings decreases and losses", Journal of Accounting and Economics, vol. 24, no. 1: $99-126$

Cascino, S., Pugliese, A., Mussolino, D. \& Sansone, C. (2010) "The influence of family ownership on the quality of accounting information", Family Business Review, vol. 23, no. 3: 246-265

Cennamo, C., Berrone, P., Cruz, C. \& Gomez-Mejia, L. R. (2012) "Socioemotional wealth and proactive stakeholder engagement: Why family-controlled firms care more about their stakeholders", Entrepreneurship theory and practice, vol. 36, no. 6: 1153-1173

Chavali, K. \& Rosario, S. (2018) "Relationship between Capital Structure and Profitability: A Study of Non Banking Finance Companies in India", Academy of Accounting and Financial Studies Journal

Chen, C. J. \& Jaggi, B. (2000) "Association between independent non-executive directors, family control and financial disclosures in Hong Kong", Journal of Accounting and Public policy, vol. 19, no. 4-5: 285-310

Chen, T. Y., Gu, Z., Kubota, K. \& Takehara, H. (2015) "Accrual-Based and Real Activities Based Earnings Management Behavior of Family Firms in Japan", The Japanese Accounting Review, vol. 5, no. 2015: 21-47

Chi, C. W., Hung, K., Cheng, H. W. \& Lieu, P. T. (2015) "Family firms and earnings management in Taiwan: Influence of corporate governance", International Review of Economics \& Finance, vol.36: 88-98.

Chrisman, J. J., Chua, J. H. \& Litz, R. A. (2004) "Comparing the agency costs of family and non-family firms: Conceptual issues and exploratory evidence", Entrepreneurship theory and practice, vol. 28, no. 4: 335-354 
Chu, W. (2009) "The influence of family ownership on SME performance: evidence from public firms in Taiwan", Small Business Economics, vol. 33, no. 3: 353-373

Chua, J. H., Chrisman, J. J. \& Sharma, P. (1999) "Defining the Family Business by Behavior", Entrepreneurship theory and practice, vol. 23; no. 4: 19-39

Cohen, D. A., Dey, A. \& Lys, T. Z. (2008) "Real and Accrual-Based Earnings Management in the Pre- and Post-Sarbanes-Oxley Periods", The Accounting Review, vol. 83, no. 3: 757-787

Cohen, D. A. \& Zarowin, P. (2010) "Accrual-based and real earnings management activities around seasoned equity offerings", Journal of Accounting and Economics, vol. 50, no. 1: 2-19

Cormier, D., Magnan, M. \& Morard, B. (1998) "La gestion stratégique des résultats : Le modèle anglo-saxon convient-il au contexte suisse ? [Earnings Management: Is the Anglo-Saxon Model Relevant to the Swiss Context?]", Comptabilité - Contrôle - Audit, vol. 4, no. 1: 25-48

Debnath, P. (2017) "Assaying the Impact of Firm's Growth and Performance on Earnings Management: An Empirical Observation of Indian Economy", International Journal, vol. 30.

Dechow, P. M., Sloan, R. G. \& Sweeney, A. P. (1995) "Detecting earnings management", Accounting Review, 193-225

DeFond, M. L. \& Park, C. W. (1997) "Smoothing income in anticipation of future earnings", Journal of Accounting and Economics, vol. 23, no. 2: 115-139

Degeorge, F., Patel, J. \& Zeckhauser, R. (1999) "Earnings management to exceed thresholds", The Journal of Business, vol. 72, no. 1: 1-33

Ding, S., Qu, B. \& Zhuang, Z. (2011) "Accounting properties of Chinese family firms", Journal of Accounting, Auditing \& Finance, vol. 26, no. 4: 623-640

Embong, Z. \& Hosseini, L. (2018) "Analyst forecast accuracy and earnings management", Asian Journal of Accounting and Governance, vol. 10: 97-108

Eng, L. L., Fang, H., Tian, X., Yu, T. R. \& Zhang, H. (2019) "Financial crisis and real earnings management in family firms: A comparison between China and the United States", Journal of International Financial Markets, Institutions and Money, vol. 59: 184-201

Faccio, M., Lang, L. H. P. \& Young, L. (2001) "Dividends and Expropriation", American Economic Review, vol. 91, no. 1: 54-78

Fama, E. F. \& Jensen, M. C. (1983) "Agency problems and residual claims", The journal of law and Economics, vol. 26, no. 2: 327-349

Fan, J. P. \& Wong, T. J. (2002) "Corporate ownership structure and the informativeness of accounting earnings in East Asia", Journal of Accounting and Economics, vol.33, no. 3: 401-425

Fung, S. Y. \& Goodwin, J. (2013) "Short-term debt maturity, monitoring and accruals-based earnings management", Journal of Contemporary Accounting \& Economics, vol. 9, no. 1: 67-82 
Gómez-Mejía, L. R., Cruz, C., Berrone, P. \& De Castro, J. (2011) "The bind that ties: Socioemotional wealth preservation in family firms", Academy of Management Annals, vol. 5, no. 1: 653-707

Gómez-Mejía, L. R., Cruz, C. \& Imperatore, C. (2014) "Financial reporting and the protection of socioemotional wealth in family-controlled firms", European Accounting Review, vol. 23, no. 3: 387-402

Gómez-Mejía, L. R., Haynes, K. T., Núñez-Nickel, M., Jacobson, K. J. \& MoyanoFuentes, J. (2007) "Socioemotional wealth and business risks in familycontrolled firms: Evidence from Spanish olive oil mills", Administrative Science Quarterly, vol. 52, no. 1: 106-137

Gómez-Mejía, L. R., Makri, M. \& Kintana, M. L. (2010) "Diversification decisions in family-controlled firms", Journal of management studies, vol. 47, no. 2: 223-252

Graham, J. R., Harvey, C. R. \& Rajgopal, S. (2005) "The economic implications of corporate financial reporting", Journal of Accounting and Economics, vol. 40, no. 1-3: 3-73

Gujarati, D. N. (2003) Basic Econometrics, fourth edition McGraw-Hill, New York

Gunny, K. A. (2005) "What are the consequences of real earnings management?", Cahier de recherche, Haas School of Business, University of California.: Citeseer

Jara-Bertin, M. \& Sepulveda, J. P. (2016) "Earnings management and performance in family-controlled firms: Evidence from an emerging economy", Academia Revista Latinoamericana de Administración, vol. 29, no. 1: 44-64

Jelinek, K. (2007) "The effect of leverage increases on earnings management", The Journal of Business and Economic Studies, vol. 13, no. 2: 24

Jennifer, A., Beatty, A. L. \& Weber, J. (2005) "The Effects of Accelerated Revenue Recognition on Earnings Management and Earnings Informativeness: Evidence from SEC Staff Accounting Bulletin no. 101", The Accounting Review, vol. 80, no. 2: 373-401

Jensen, M. C. (1986) "Agency costs of free cash flow, corporate finance, and takeovers", The American Economic Review, vol. 76, no. 2: 323-329

Jensen, M. C. (2005) "Agency costs of overvalued equity", Financial Management, vol. 34, no. 1: 5-19

Jensen, M. C. \& Meckling, W. H. (1976) "Theory of the firm: Managerial behavior, agency costs and ownership structure", Journal of Financial Economics, vol. 3, no. 4: 305-360

Jiraporn, P. \& DaDalt, P. J. (2009) "Does founding family control affect earnings management?", Applied Economics Letters, vol. 16, no. 2: 113-119

Klein, A. (2002) "Audit committee, board of director characteristics, and earnings management", Journal of Accounting and Economics, vol. 33, no. 3: $375-400$

La Porta, R., Lopez-De-Silanes, F. \& Shleifer, A. (1999) "Corporate Ownership Around the World", The journal of finance, vol. 54, no. 2: 471-517 
La Porta, R., Lopez-de-Silanes, F. \& Shleifer, A. (2006) "What works in securities laws?", The journal of finance, vol. 61, no. 1:1-32

La Porta, R., Lopez-de-Silanes, F., Shleifer, A. \& Vishny, R. W. (2000) “Agency problems and dividend policies around the world", The journal of finance, vol. 55 , no. 1: 1-33

Labelle, R. (1990) "Bond covenants and changes in accounting policy: Canadian evidence", Contemporary accounting research, vol. 6, no. 2: 677-698

Larcker, D. F. \& Richardson, S. A. (2004) "Fees paid to audit firms, accrual choices, and corporate governance", Journal of Accounting Research, vol. 42, no. 3: 625-658

Leuz, C., Nanda, D. \& Wysocki, P. D. (2003) "Earnings management and investor protection: an international comparison", Journal of Financial Economics, vol. 69 , no. 3: 505-527

Malik, S. A. \& Ahmad, A. C. (2017) "Auditor Tolerance of Accrual-Based and Real Earnings Management in Boardrooms of Politically Connected Nigerian Firms", Asian Journal of Accounting and Governance, vol. 8: $101-111$

Mard, Y. \& Marsat, S. (2012) "Gestion des résultats comptables et structure de l'actionnariat: le cas français", Comptabilité-Contrôle-Audit, vol. 18, no. 3: $11-42$

Martin, G., Campbell, J. T. \& Gomez-Mejia, L. (2016) "Family Control, Socioemotional Wealth and Earnings Management in Publicly Traded Firms", Journal of Business Ethics, vol. 133: 453-469

McVay, S. E. (2006) "Earnings management using classification shifting: An examination of core earnings and special items", The Accounting Review, vol. 81 , no. 3: 501-531

Miller, D. \& Le Breton-Miller, I. (2006) "Priorities, practices and strategies in successful and failing family businesses: An elaboration and test of the configuration perspective", Strategic Organization, vol. 4, no. 4: 379-407

Ouellet, E., Belley-Ferris, I. \& Leblond, S. (2005) Guide d'économétrie appliquée pour Stata Pour ECN 3950 et FAS 3900 University of Montreal

Paiva, I. S., Lourenço, I. C. \& Branco, M. C. (2016) "Earnings management in family firms: current state of knowledge and opportunities for future research", Review of Accounting and Finance, vol. 15, no. 1: 85-100

Pazzaglia, F., Mengoli, S. \& Sapienza, E. (2013) "Earnings quality in acquired and nonacquired family firms: A socioemotional wealth perspective", Family Business Review, vol. 26, no. 4: 374-386

Prencipe, A. \& Bar-Yosef, S. (2011) "Corporate governance and earnings management in family-controlled companies", Journal of Accounting, Auditing \& Finance, vol. 26, no. 2: 199-227

Prencipe, A., Bar-Yosef, S. \& Dekker, H. C. (2014) "Accounting research in family firms: Theoretical and empirical challenges", European Accounting Review, vol. 23, no. 3: 361-385

Prencipe, A., Markarian, G. \& Pozza, L. (2008) "Earnings management in family firms: Evidence from R\&D cost capitalization in Italy", Family Business Review, vol. 21, no. 1: 71-88 
Razzaque, R. M. R., Ali, M. J. \& Mather, P. R. (2016) "Real earnings management in family firms: Evidence from an emerging economy", Pacific-Basin Finance Journal, vol. 40: 237-250

Rodriguez-Ariza, L., Martínez-Ferrero, J. \& Bermejo-Sánchez, M. (2016) "Consequences of earnings management for corporate reputation: Evidence from family firms", Accounting Research Journal, vol. 29, no. 4: 457-474

Roychowdhury, S. (2006) "Earnings management through real activities manipulation", Journal of Accounting and Economics, vol. 42, no. 3: 335-370

Salvato, C. \& Moores, K. (2010) "Research on Accounting in Family Firms: Past Accomplishments and Future Challenges", Family Business Review, vol. 23, no. 3: 193-215

Schulze, W. S., Lubatkin, M. H. \& Dino, R. N. (2003a) "Toward a theory of agency and altruism in family firms", Journal of Business Venturing, vol. 18, no. 4: 473-490

Shleifer, A. \& Vishny, R. W. (1997) "A survey of corporate governance", The journal of finance, vol. 52, no. 2: 737-783

Stein, J. C. (1989) "Efficient capital markets, inefficient firms: A model of myopic corporate behavior", The Quarterly Journal of Economics, vol. 104, no. 4, 655-669

Stockmans, A., Lybaert, N. \& Voordeckers, W. (2010) "Socioemotional wealth and earnings management in private family firms", Family Business Review, vol. 23, no. 3: 280-294

Strike, V. M., Berrone, P., Sapp, S. G. \& Congiu, L. (2015) "A socioemotional wealth approach to CEO career horizons in family firms", Journal of management studies, vol. 52, no. 4: 555-583

Subramanyam, K. R. (1996) "The pricing of discretionary accruals", Journal of Accounting and Economics, vol. 22, no. 1:249-281

Tai, Y.-H. (2017) "Earnings management in family firms: the role of inside directors", Journal de gestion de l'Université Jiaotong, vol. 37, no. 1: $77-114$

Tong, Y. H. (2007) "Financial reporting practices of family firms", Advances in Accounting, vol. 23: 231-261

Wang, D. (2006) "Founding family ownership and earnings quality", Journal of Accounting Research, vol. 44, no. 3: 619-656

Watts, R. L. \& Zimmerman, J. L. (1978) "Towards a positive theory of the determination of accounting standards", Accounting Review, 112-134

Wu, C. \& Huang, L. (2011) "Market expectations and discretionary accruals", Paper presented at the International Symposium on Finance and Accounting, Bangkok

Zang, A. Y. (2011) "Evidence on the trade-off between real activities manipulation and accrual-based earnings management", The Accounting Review, vol. 87, no. 2: $675-703$

ii «Leadership Lessons from Great Family Businesses», Harvard Business Review, April 2015) 